\title{
PENERAPAN MODEL KOOPERATIF TIPE TPS TERHADAP HASIL BELAJAR KOGNITIF DAN AKTIVITAS PESERTA DIDIK PADA MATERI GELOMBANG MEKANIK KELAS XI IPA SMA NEGERI 1 KABUPATEN SORONG
}

\author{
Tirza Pangkali ${ }^{1}$, Iriwi L.S. Sinon ${ }^{2}$, Sri Wahyu Widyaningsih ${ }^{3}$ \\ 1, 2, ${ }^{3}$ Prodi Pendidikan Fisika FKIP UNIPA Jalan Gunung Salju Amban Manokwari Papua Barat 98314 \\ e-mail: ${ }^{1}$ tirzapangkali130@gmail.com, ${ }^{2}$ i.sinon@unipa.ac.ad, ${ }^{3}$ s.widyaningsih@unipa.ac.ad
}

Diterima: 19 Agustus 2016. Disetujui: 12 Oktober 2016. Dipublikasikan: Oktober 2016

\begin{abstract}
This study aims to determine and measuring the differences of the cognitive learning and activity on learners using direct instruction and cooperative TPS type in class XI IPA SMA Negeri 1 Sorong. This research is Quasi-experimental research which used The Matching Only Posttest Control Group Design. This study occur on two classes; XI IPA 1 as an experimental class and class XI IPA 2 as the control class. The results shows that the average cognitive achievement test at 78,82 and the average activity 88,66, while the control class 70,59 and the average activity 84,21. It shows the results of learning and activity using TPS type of cooperative learning more effective. The results of data processing using independent sample $t$-test, with significance level $\alpha=5 \%$ obtained $t=2,396$. Value $t_{\text {tabel }}=1,694$ so $t_{\text {hitung }}>t_{\text {tabel }}$ which means $H_{0}$ rejected, so there are significant differences of cognitive achievement between control and experimental class.
\end{abstract}

\begin{abstract}
Abstrak: Penelitian ini bertujuan untuk mengetahui dan mengukur perbedaan hasil belajar kognitif dan aktivitas peserta didik menggunakan model pembelajaran direct instruction dan kooperatif tipe TPS di kelas XI IPA SMA Negeri 1 Kabupaten Sorong. Penelitian kuasi eksperimen ini menggunakan The Matching Only Posttest Control Group Design. Penelitian ini sebanyak dua kelas yaitu kelas XI IPA 1 sebagai kelas eksperimen dan kelas XI IPA 2 sebagai kelas kontrol. Hasil penelitian menunjukkan bahwa rata-rata tes hasil belajar kognitif kelas eksperimen sebesar 78,82 dan rata-rata aktivitas peserta didik 88,66 , sedangkan kelas kontrol 70,59 dan rata-rata aktivitas peserta didik 84,21. Hal ini menunjukan hasil belajar dan aktivitas dengan menggunakan pembelajaran kooperatif tipe TPS lebih efektif. Hasil pengolahan data menggunakan Independent Sample t-test dengan taraf signifikan $\alpha=5 \%$ diperoleh thitung $=$ 2,396. Nilai $t_{\text {tabel }}=1,694$ sehingga $t_{\text {hitung }}>t_{\text {tabel }}$ yang berarti $\mathrm{H}_{0}$ ditolak sehingga terdapat perbedaan yang signifikan hasil belajar kognitif antara kelas kontrol dengan eksperimen.
\end{abstract}

(C) 2016 Pendidikan Fisika, FTK IAIN Raden Intan Lampung

Kata kunci: aktivitas, hasil belajar, kooperatif tipe TPS

\section{PENDAHULUAN}

Pendidikan merupakan salah satu bagian terpenting dalam fase kehidupan manusia yang akan menentukan peradaban manusia pada masa yang akan datang (Widyaningsih, S.W \& Yusuf, I, 2015: 681). Menurut UU No. 20 tahun 2003, tentang sistem Pendidikan Nasional:

"Pendidikan adalah usaha sadar dan terencana untuk mewujudkan suasana belajar dan proses pembelajaran agar peserta didik secara aktif mengembangkan potensi dirinya untuk memiliki kekuatan spiritual keagamaan, pengendalian diri, kepribadian, kecerdasan, akhlak mulia, serta keterampilan yang diperlukan."

Output dari pendidikan ini berupa pengetahuan dan keterampilan, dan perilaku yang diterima masyarakat. Karena tujuan pendidikan pada dasarnya adalah untuk mengantarkan peserta didik menuju perubahan-perubahan tingkah laku, baik berupa pengetahuan, sikap, moral, maupun sosial agar hidup mandiri 
sebagai makhluk individu dan hidup bermasyarakat dengan baik sebagai makhluk sosial (Chasanah, U.U, dkk, 2016: 25).

Menurut Saenab (2012) pendidikan yang efektif adalah suatu pendidikan yang memungkinkan peserta didik untuk dapat belajar dengan mudah, menyenangkan dan tujuan dapat tercapai sesuai dengan yang diharapkan, dengan demikian pendidik dituntut untuk dapat meningkatkan keefektifan pembelajaran.

Belajar dimulai dengan adanya dorongan dan semangat. Dalam proses pelaksanaan pembelajaran, guru selalu dituntut untuk meningkatkan kualitasnya dalam pembelajaran. Kualitas guru dapat ditinjau dari dua segi, yaitu segi proses dan segi hasil. Kusuma (2012) menjelaskan bahwa dari segi proses, guru dapat dikatakan berhasil apabila mampu melibatkan sebagian besar peserta didik secara aktif, baik fisik, mental, maupun sosial dalam pembelajaran. Sedangkan dari segi hasil, guru dikatakan berhasil apabila pembelajaran yang diberikannya mampu mengubah perilaku sebagian besar peserta didik kearah penguasaan kompetensi dasar yang lebih baik.

Menurut Mufidah (2013) "aktivitas peserta didik selama pembelajaran mencerminkan adanya motivasi ataupun keinginan peserta didik untuk belajar". Dalam kegiatan belajar mengajar kedua Dalam proses pembelajaran aktivitas belajar merupakan unsur yang sangat penting karena pada dasarnya belajar adalah berbuat.

$$
\text { Proses pembelajaran pada }
$$

Kurikulum 2013 untuk semua jenjang, dilaksanakan dengan pendekatan ilmiah (scientific approach). Pendekatan scientific dalam pembelajaran sebagaimana dimaksud meliputi: mengamati, menanya, mengumpulkan data, mengasosiasi dan mengkomunikasikan. Kurikulum 2013 mengutamakan nilai kompetensi berimbang yakni: kompetensi sikap, keterampilan dan pengetahuan.

Widyaningsih, S.W (2011: 299) mengatakan bahwa fisika adalah bagian dari ilmu pengetahuan alam yang merupakan hasil kegiatan manusia berupa pengetahuan, gagasan dan konsep yang terorganisir tentang alam sekitar yang diperoleh dari pengalaman melalui serangkaian proses ilmiah. "Pembelajaran fisika bertujuan untuk memberikan bekal pengetahuan tentang fisika, kemampuan dalam keterampilan proses serta meningkatkan kreativitas dan sikap ilmiah pada peserta didik" (Candra, 2013). Menurut pendapat tersebut, peserta didik dapat memperoleh pengetahuan, keterampilan dan sikap ilmiah mengenai gejala atau fenomena alam, sehingga peserta didik dituntut untuk aktif dalam proses pembelajaran, bukan hanya sekedar menghafal teori dan rumus saja. Sedangkan, pada hakikat pembelajaran Kurikulum 2013, peserta didik diharapkan mampu menghubungkan teori yang diperoleh dengan kehidupan nyata seharihari.

$\begin{array}{ccc}\begin{array}{c}\text { Kenyataan } \\ \text { menunjukkan }\end{array} & \text { di } & \text { lapangan } \\ \text { bonwa } & \text { kondisi }\end{array}$ pembelajaran fisika masih tidak sesuai dengan teori tersebut, sebagian peserta didik masih menganggap fisika merupakan mata pelajaran yang sulit dan membosankan karena mereka kesulitan untuk memahami konsep fisika, banyaknya rumus yang harus dihafal tanpa dituntut untuk memahami dan mengembangkan informasi yang dapat diaplikasikan dalam kehidupan seharihari, sehingga menyebabkan rendahnya ketuntasan hasil belajar dan aktivitas peserta didik. Agar pembelajaran fisika tidak membuat peserta didik jenuh, maka guru harus kreatif dan mampu memotivasi peserta didik (Jurmani, 2014).

SMA Negeri 1 Kabupaten Sorong merupakan salah satu sekolah menengah atas yang berada di Kabupaten Sorong yang menerapkan Kurikulum 2013. Hasil 
observasi dan wawancara dengan guru mata pelajaran fisika menyatakan bahwa ketuntasan belajar peserta didik di bawah kriteria ketuntasan minimum (KKM) 70. Rendahnya hasil belajar peserta didik karena kurangnya peran peserta didik dalam proses pembelajaran.

Pembelajaran Kurikulum 2013 merupakan pembelajaran yang berpusat pada peserta didik. Oleh karena itu, untuk melihat hasil belajar dan aktivitas peserta didik maka pembelajaran yang semula berpusat pada guru menjadi berpusat pada peserta didik.

Dalam proses pembelajaran, peserta didik perlu mengerti apa makna yang dipelajarinya, apa manfaatnya, dalam status apa mereka, dan bagaimana cara mencapainya (Widyaningsih, S.W \& Yusuf, I, 2015: 224). Hal ini dapat dilakukan dengan cara menerapkan model pembelajaran kooperatif tipe TPS (think Pair share) di kelas XI IPA SMA Negeri 1 Kabupaten Sorong yang memiliki kemampuan di bawah nilai Kriteria Ketuntasan Minimal (KKM). "TPS memberikan kesempatan lebih banyak kepada peserta didik untuk berpikir, untuk merespon, dan untuk saling membantu" (Arends, 2008).

Model pembelajaran kooperatif tipe TPS adalah salah satu model pembelajaran yang cukup efektif untuk meningkatkan hasil belajar peserta didik karena peserta didik dituntut melakukan aktivitas lebih banyak saat belajar. Keutamaan model pembelajaran tipe TPS yaitu dapat menumbuhkan keterlibatan peserta didik dengan memberikan kesempatan terbuka pada peserta didik untuk berbicara, mengutarakan gagasannya sendiri dan memotivasi peserta didik untuk terlibat percakapan dalam kelas. Dengan demikian menggunakan model pembelajaran kooperatif tipe TPS dapat membantu peserta didik dalam berkomunikasi untuk menyampaikan informasi, seperti menyatakan ide, mengajukan pertanyaan dan menanggapi pertanyaan orang lain (Marlina, 2014).

Langkah-langkah pembelajaran kooperatif adalah sebagai berikut:

Tabel 1. Langkah-langkah pembelajaran kooperatif

\begin{tabular}{cl} 
Kegiatan & \multicolumn{1}{c}{$\begin{array}{c}\text { Langkah-Langkah Model } \\
\text { Kooperatif }\end{array}$} \\
\hline Pendahuluan & $\begin{array}{l}\text { Fase 1 Menyampaikan Tujuan } \\
\text { dan Memotivasi Peserta Didik }\end{array}$ \\
\hline Inti & Fase 2 Menyajikan Informasi \\
\cline { 2 - 2 } & $\begin{array}{l}\text { Fase 3 Mengorganisasikan } \\
\text { Peserta Didik kedalam } \\
\text { Kelompok Kooperatif }\end{array}$ \\
\cline { 2 - 2 } & $\begin{array}{l}\text { Fase 4 Membimbing kelompok } \\
\text { Belajar }\end{array}$ \\
\hline Penutup & Fase 5 Evaluasi \\
\cline { 2 - 2 } & Fase 6 Memberi Penghargaan \\
\hline
\end{tabular}

(Nurlaila, 2013)

Dalam proses belajar mengajar tidak ada model pembelajaran yang sempurna. Suatu model pembelajaran pasti mempunyai kelebihan dan kekurangan masing-masing. Kelebihan model kooperatif tipe TPS Menurut Miftahul (Kuswati, 2011) yaitu: meningkatkan partisipasi, cocok untuk tugas-tugas yang sederhana, masing-masing anggota memiliki lebih banyak kesempatan untuk berkontribusi pada kelompoknya, interaksi lebih mudah, pembentukkannya lebih cepat dan mudah.

Sedangkan kekurangan model pembelajaran kooperatif tipe TPS yaitu: banyak kelompok yang akan melapor tugasnya pada guru, guru harus banyak memonitor banyak kelompok, lebih sedikit ide yang muncul, dan jika ada perselisihan tidak ada penengah.

Berdasarkan permasalahan yang dihadapi peserta didik dan guru dalam proses pembelajaran di kelas dan solusi yang ada untuk menghadapi permasalahan tersebut, maka perlu diadakan suatu penelitian untuk meningkatkan hasil belajar dan aktivitas peserta didik. Hal ini yang menjadi latar belakang penulis melakukan penelitian dengan judul: "penerapan model kooperatif tipe TPS 
untuk meningkatkan hasil belajar kognitif dan aktivitas peserta didik pada materi gelombang mekanik kelas XI IPA SMA Negeri 1 Kabupaten Sorong".

Aktivitas belajar peserta didik sangat diperlukan, karena prinsipnya belajar itu berbuat atau melakukan aktivitas. Aktivitas belajar adalah keterlibatan peserta didik dalam sikap, pikiran, perhatian dalam belajar guna keberhasilan proses pembelajaran. Pada penelitian ini aktivitas peserta didik yang diamati yaitu memperhatikan penjelasan guru, diskusi, bertanya, berpendapat, memberi saran dan laporan. Aktivitas peserta didik akan diukur pada lembar observasi. Sedangkan, hasil belajar peserta didik yang akan diteliti pada ranah kognitif yaitu mengingat (C1), memahami (C2), mengaplikasikan (C3) dan menganalisis (C4).

\section{METODE PENELITIAN}

Penelitian ini dilaksanakan dengan metode kuasi eksperimen. Metode quasi eksperimen adalah metode penelitian dengan memberikan perlakuan tertentu pada sampel penelitian. Metode ini tidak mengambil subjek secara acak dari populasi tetapi menggunakan seluruh subjek dalam kelompok yang utuh (intact group) untuk diberikan perlakuan (treatment).

Desain penelitian yang digunakan pada penelitian ini adalah The Matching Only Posttest Control Group Design (Fraenkel, J.R. \& Wallen, N.E. 2009: 271). Rancangan ini melibatkan hasil belajar kognitif dari dua kelompok yang dibandingkan yaitu kelompok eksperimen dan kelompok kontrol berdasarkan pengukuran akhir dari dua kelompok. Kelompok eksperimen diajarkan menggunakan model kooperatif tipe TPS dan kelas kontrol menggunakan model konvensional yaitu Directt Instruction.

Teknik analisis data pada penelitian ini menggunakan uji homogenitas digunakan untuk mengetahui apakah sampel dari populasi yang homogen atau tidak homogen. Uji homogenitas dilakukan dengan melihat keadaan kehomogenan populasi. Peneliti menggunakan uji Levene's test dan ANOVA untuk melihat data kelas eksperimen dan kontrol homogen atau tidak. Kedua kelas dinyatakan homogen bila nilai sig $>0,05$.

Tahap akhir uji hipotesis ini digunakan untuk mengetahui adanya pengaruh penerapan model pembelajaran kooperatif tipe snowball throwing terhadap hasil belajar kognitif peserta didik. Uji hipotesis ini dilakukan untuk melihat perbedaan yang signifikan hasil tes dari kelompok eksperimen dan kelompok kontrol. Karena data homogen dan terdistribusi normal maka uji yang digunakan dalam penelitian ini menggunakan rumus uji " $t$ ". Uji “ $t$ " adalah salah satu tes statistik yang dipergunakan untuk menguji kebenaran atau kepalsuan hipotesis nihil yang menyatakan bahwa diantara dua buah mean sampel yang diambil tidak terdapat perbedaan yang signifikan.

Dalam pengujian tersebut peneliti menggunakan software SPSS 22 untuk analisis uji normalitas, homogenitas dan uji t. Nilai thitung dibandingkan dengan nilai $t_{\text {tabel }}$ pada taraf signifikan 5\% $(\alpha=$ $0,05)$. Apabila nilai $t_{\text {hitung }}<t_{\text {tabel }}$ maka $\mathrm{H}_{0}$ diterima. Sebaliknya jika nilai $t_{\text {hitung }}>t_{\text {tabel }}$ berarti $\mathrm{H}_{0}$ ditolak. Adapun perumusan hipotesis statistik penelitian adalah:

$\begin{array}{ll}\mathrm{H}_{0} & : \mu_{1}=\mu_{2} \\ \mathrm{H}_{\mathrm{a}} & : \mu_{1 \neq} \mu_{2}\end{array}$

Keterangan:

$\mathrm{H}_{0}$ : hipotesis nihil atau hipotesis nol

$\mathrm{H}_{\mathrm{a}}$ : hipotesis alternatif

$\mu_{1}$ : rata-rata hasil belajar kognitifkelompok eksperimen

$\mu_{2}$ : rata-rata hasil belajar kognitif kelompok kontrol 


\section{HASIL DAN PEMBAHASAN}

Pengujian persyaratan analisis data pada penelitian ini meliputi uji normalitas dan uji homogenitas. Uji normalitas dan Tabel 2. Hasil uji normalitas homogenitas di kelas ekperimen dan kelas kontrol dilakukan dengan menggunakan SPSS 22.

\begin{tabular}{cccccccc}
\hline & \multicolumn{9}{c}{ Tests of Normality } & & & \\
\hline & \multirow{2}{*}{ Metode } & \multicolumn{2}{c}{ Kolmogorov-Smirnov ${ }^{\mathrm{a}}$} & \multicolumn{3}{c}{ Shapiro-Wilk } \\
\cline { 3 - 8 } & & Statistic & df & Sig. & Statistic & df & Sig. \\
\hline Hasil & Eksperimen & .158 & 17 & $.200^{*}$ & .946 & 17 & .393 \\
\cline { 2 - 8 } Belajar & Kontrol & .180 & 17 & .146 & .937 & 17 & .282 \\
\hline
\end{tabular}

Berdasarkan Tabel 2, terlihat bahwa data kemampuan kognitif peserta didik pada kelas yang menggunakan model kooperatif tipe TPS dan kelas yang menggunakan model pembelajaran konvensional kedua-duanya terdistribusi normal. Pada uji normalitas kolmogorovSmirnov dengan $a=5 \%$, nilai signifikan $>$ dari 0,05 sehingga $H_{0}$ di tolak. Artinya terdapat perbedaan yang signifikan hasil belajar yang kognitif antara kelompok eksperimen dan kelompok kontrol. Begitu pula uji normalitas Shapiro-Wilk dengan $a=5 \%$, nilai signifikan $>0,05$ maka $H_{0}$ ditolak. Grafik yang menunjukan data terdistribusi normal untuk kelas eksperimen dan kelas kontrol adalah sebagai berikut.

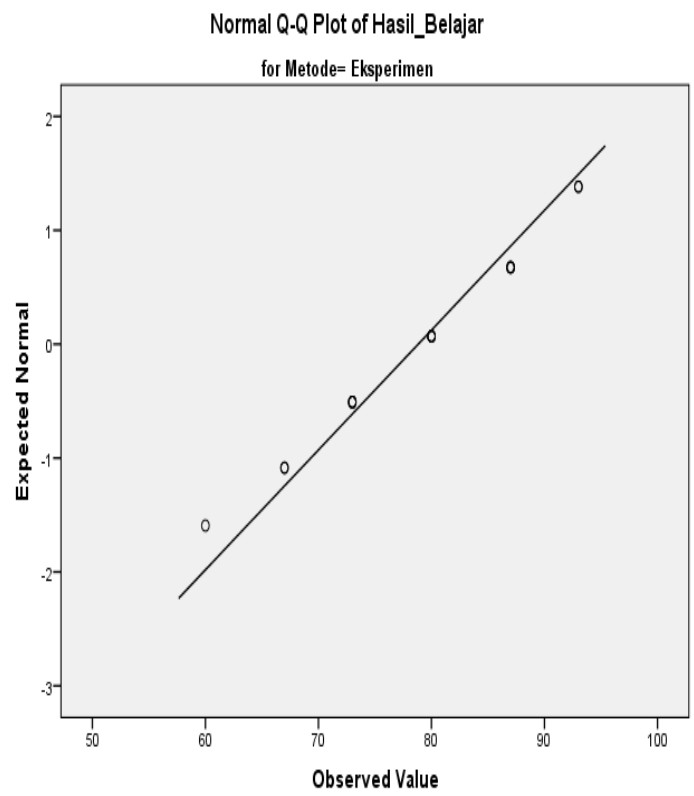

Gambar 1 Uji Normalitas Kelas Eksperimen

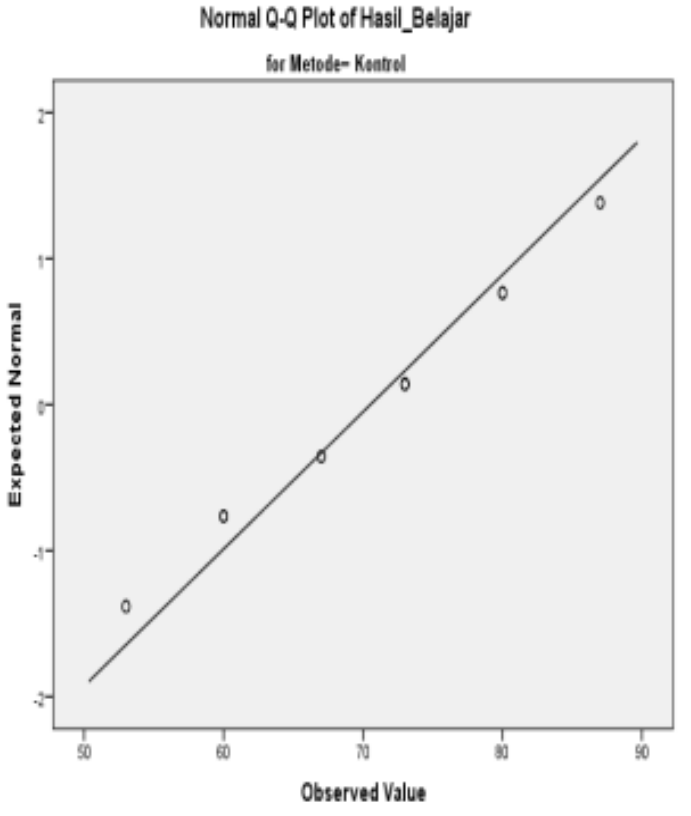

Gambar 2 Uji Normalitas Kelas Kontrol

Berdasarkan grafik uji normalitas, untuk kelas eksperimen dan kelas kontrol terdistribusi normal. Hal tersebut terlihat dari grafik terbentuk linear. Tahap selanjutnya setelah data terdistribusi normal yaitu melakukan uji homogenitas untuk membuktikan varians dari kedua kelas homogen atau tidak.

Tabel 3. Hasil uji homogenitas dengan levene Statistic

Test of Homogeneity of Variances

\begin{tabular}{cccc}
\hline \multicolumn{4}{c}{ Hasil_Belajar } \\
\hline Levene Statistic & df1 & df2 & Sig. \\
\hline .247 & 1 & 32 & .623 \\
\hline
\end{tabular}

Kedua kelas dinyatakan homogen bila sig $>$ 0,05. Berdasarkan Tabel 3 terlihat 
bahwa varians kedua kelas homogen dengan $a=5 \%$. Pada Levene's Test, nilai signifikannya yaitu $0,623>0,05$. Artinya data tergolong homogen, karena data terdistribusi normal dan homogen, analisis data dilanjutkan dengan uji inferensial/ uji hipotesis menggunakan Independent Sample t-test.

\section{Pengujian Hipotesis}

Pengujian hipotesis menggunakan SPSS 22. Hasil pengujian uji independent Sampel t-test dengan taraf signifikan $a=$ $5 \%$ atau 0,05 diperoleh $t_{\text {hitung }}$ 2,396, sedangkan nilai $t_{\text {tabel }}$ yaitu 1,694. Nilai thitung $>\mathrm{t}_{\text {tabel }}$ maka $H_{0}$ ditolak, maka terdapat perbedaan yang signifikan hasil belajar kognitif peserta didik antara kelompok eksperimen dan kelompok kontrol. Pengambilan keputusan "terdapat perbedaan" karena hasil uji t diperoleh sig $>0,05$. Uji ini dilakukan pada soal yang diberikan diakhir proses pembelajaran (posstest).

\section{Pembahasan Hasil Penelitian.}

Berdasarkan hasil analisis posstest diperoleh hasil yang dapat digunakan untuk mengetahui uji hipotesis. Uji hipotesis dilaksanakan setelah dilakukan uji normalitas dan homogenitas pada kelas eksperimen dan kelas kontrol yang digunakan. Uji homogenitas dapat dilihat pada Tabel 3. Pada tabel tersebut diperoleh signifikansi 0,623. Nilai signifikansi $0,623>0,05$ menunjukan bahwa kedua kelas homogen. Hasil pengujian Independent Sample t-test dengan taraf signifikan $a=5 \%$ maka $H_{0}$ ditolak. Artinya terdapat perbedaan yang signifikan hasil belajar kognitif antara kelompok eksperimen dengan kelompok kontrol. Pengambilan keputusan terdapat perbedaan karena hasil uji t diperoleh sig $>0,05$. Uji ini dilakukan pada soal yang diberikan diakhir proses pembelajaran (posstest).

Pengujian hipotesis diputuskan bahwa $H_{0}$ (tidak terdapat perbedaan yang signifikan hasil belajar kognitif peserta didik yang diajar menggunakan model kooperatif tipe TPS dengan diajar menggunakan model konvensional) ditolak. Pengujian tersebut menunjukkan adanya perbedaan penerapan model kooperatif tipe TPS dengan model pembelajaran konvensional terhadap kemampuan kognitif peserta didik. Bellina, S., \& Motlan (2013) dan Candra (2013) mengatakan bahwa terdapat perbedaan hasil belajar yang signifikan pembelajaran kooperatif tipe TPS. Hal ini dibuktikan dengan rata-rata nilai peserta didik kelas eksperimen lebih baik dari kelas kontrol.

Perbedaan hasil belajar kelas eksperimen dengan kelas kontrol karena kelas eksperimen menerapkan model kooperatif tipe TPS yang melibatkan 2 orang siswa dalam satu kelompok sedangkan kelas kontrol menerapkan model Directt Instruction yang melibatkan 4-6 siswa dalam satu kelompok. Pembelajaran dengan model kooperatif tipe TPS peserta didik dituntut untuk memahami materi pelajaran dengan cara berpikir, berpasangan, dan berbagi. Setiap peserta didik bertangung jawab untuk menguasai materi dengan cara berpikir sendiri terlebih dahulu, bertukar pikiran atau bertukar informasi dengan teman sekelompoknya, sehingga peserta didik yang pasif dan hanya mendengarkan saja tidak ditemukan lagi pada pembelajaran ini, melainkan peserta didik menjadi aktif untuk belajar. Hal ini sesuai dengan pendapat Isjoni (2012) yang menyatakan pembelajaran dengan menggunakan kelompok-kelompok kecil membuat peserta didik dapat bekerja sama untuk mencapai tujuan pembelajaran. Penelitian oleh Giyastutik (2009) komunikasi kelompok memberikan dampak agar setiap peserta didik mempunyai keahlian untuk mendengarkan dan berbicara. Keberhasilan pembelajaran tersebut karena guru memberikan kesempatan 
pada peserta didik untuk mengembangkan pengetahuan yang dimiliki dan guru menempatkan diri sebagai motivator dan fasilitator yang baik (Yusuf, I dkk, 2015: 196).

Tahap think peserta didik diberi kesempatan untuk berpikir secara mandiri. Untuk menjawab pertanyaan yang diberikan oleh guru peserta didik dapat membuat catatan kecil tentang jawaban pertanyaan sebelum berdiskusi dengan teman kelompoknya. Tahap pair, tahap ini merupakan tahap berpasangan, yaitu peserta didik mendiskusikan atau mencocokan jawaban dan saling berbagi dengan pasangan masing-masing. Sandra (2010) kegiatan diskusi dalam kelompok memberikan kesempatan pada peserta didik untuk berbicara dan saling berinteraksi dalam menyampaikan, serta menjawab pertanyaan yang diajukan teman kelompoknya. Tahap share menuntut peserta didik yang berpasangan untuk berbagi kepada seluruh kelas tentang apa yang telah mereka bicarakan. Hal ini secara efektif dapat dilakukan secara bergiliran dengan arah guru.

Penerapan model konvensional yaitu model Directt Instruction pada kelas kontrol tidak cukup buruk. Perbedaan penerapan model kooperatif tipe TPS dengan model konvensional yaitu pada kelompok belajarnya. Kelompok belajar kelas eksperimen yang menerapkan model kooperatif tipe TPS terdiri dari dua orang atau berpasang-pasangan sedangkan pada kelas kontrol yang menerapkan model konvensional terdiri dari 4 orang atau lebih. Diskusi kelompok yang terdiri dari 4 orang lebih membuat peserta didik yang lain hanya pasif dan yang lainnya bekerja sendiri mencari jawaban diskusi. Hal ini membuat peserta didik yang pasif kurang memahami materi yang diajarkan dan tidak mampu menjawab jawaban diskusi. Proses pembelajaranpun menjadi bosan dan tidak menyenangkan. Model pembelajaran kooperatif tipe TPS merupakan model yang dapat mengaktifkan peserta didik, karena model ini mengharuskan seluruh peserta didik aktif dan dapat bekerja sama dengan teman kelompoknya dengan berpasang-pasangan.

Aktivitas peserta didik selama proses pembelajaran di kelas berjalan dengan baik. Aktivitas peserta didik di kelas eksperimen dan kelas kontrol berada pada kategori cukup. Rata-rata keseluruhan aktivitas pada kelas eksperimen 84,21, dan untuk kelas kontrol 88,66. Berdasarkan data yang diperoleh melalui lembar observasi, tidak terdapat perbedaan aktivitas peserta didik di kelas eksperimen dan dikelas kontrol. Kelas eksperimen dan kelas kontrol sama-sama menggunakan pembagian kelompok belajar, dan peneliti mewajibkan peserta didik kelas eksperimen dan kelas kontrol untuk aktif dalam mengikuti pembelajaran. Penelitian ini serupa dengan penelitian oleh Galura, I.A, dkk (2016: 104) keaktifan belajar peserta didik menjadi salah satu penentu bagi keberhasilan pembelajaran yang akan berdampak pada peningkatan hasil belajar peserta didik.

\section{SIMPULAN DAN SARAN}

Berdasarkan tujuan penelitian, hasil dan pembahasan, maka kesimpulan penelitian ini yaitu:

1. Model pembelajaran Directt Instruction pada materi gelombang mekanik dengan rata-rata hasil belajar 70,59 termasuk kategori baik. Aktivitas peserta didik pada kelas kontrol dengan rata-rata 84,21 termasuk kategori baik.

2. Model pembelajaran kooperatif tipe TPS efektif digunakan pada pembelajaran gelombang mekanik yang diterapkan di kelas eksperimen dengan rata-rata hasil belajar kognitif 78,82 dalam kategori baik. Aktivitas peserta didik pada dengan nilai ratarata 88,66 dalam kategori baik. 
3. Terdapat pebedaan yang signifikan hasil belajar kognitif antara peserta didik yang menerapkan model kooperatif tipe TPS dengan model pembelajaran Direct Instruction. Ditunjukkan pada uji t yang diperoleh memiliki signifikan 0,623 dibandingkan dengan $t_{\text {hitung }} 2,396$.

Berdasarkan hasil penelitian, maka peneliti memberikan saran sebagai berikut:

1. Penerapan model kooperatif tipe TPS dapat meningkatkan hasil belajar peserta didik, sehingga model kooperatif dapat diterapkan pada pelajaran fisika khususnya pada materi gelombang mekanik.

2. Bagi peneliti selanjutnya diharapkan hasil penelitian ini dapat dijadikan rujukan dalam menerapkan model pembelajaran kooperatif tipe TPS.

\section{DAFTAR PUSTAKA}

Arends, R. I. (2011). Learning to Teach. Yogyakarta: Pustaka Pelajar.

Candra, F, dkk. (2013). Penerapan Model Pembelajaran Kooperatif Tipe TPS Disertai LKS dalam Pembelajaran Fisika di SMA. Jurnal Pendidikan Fisika, Vol.2 No.2.

Chasanah, U. U., Sinon, I. L. S., Widyaningsih, S. W. (2016). Penerapan Model Kooperatif Tipe STAD (Student Team Achivement Divisions) dengan Media Peta Konsep untuk Meningkatkan Hasil Belajar IPA Peserta Didik Kelas IX A SMP Negeri 19 Manokwari. Jurnal Pancaran. Vol. 5 No. 2.

Frankel, J.R., \& Wallen, N.E. (2009). How to Design and Evaluate Research in Eduacation ( $7^{\text {th }} \mathrm{ad}$ ). Boston: Mc Graw Hill.

Galura, I.A., Mujasam, \& Widyaningsih, S.W. (2016). Penerapan Model Kooperatif Tipe Tipe Teams Games Tousnament (TGT) untuk Meningkatkan Keaktifan dan Hasil
Belajar Fisika Peserta Didik Kelas XI IPA SMA Yapis Manokwari. Jurnal Pancaran. Vol. 5 No. 2.

Giyastutik. (2009). Penerapan Pembelajaran Kooperatif Tipe TPS Untuk Meningkatkan Hasil Belajar Biologi Siswa Kelas VII A SMP Negeri 3 Karanganyar tahun pelajaran 2007/2008. Skripsi, Universitas Sebelas Maret.

Isjoni. (2012). Pembelajaran Kooperatif. Yogyakarta: Pustaka Pelajar.

Jurmani, dkk. (2014). Pengaruh Model Pembelajaran Kooperatif Tipe TPS terhadap Pemahaman Konsep pada Pokok Bahasan Usaha dan Energi Siswa Kelas VIII SMP Negeri 9 Palu. Jurnal Pendidikan Fisika. Vol. 2 No. 1.

Kusuma, F.W. (2012). Implementasi Model Pembelajaran Kooperatif Tipe TPS untuk Meningkatkan Aktivitas Belajar Akutansi Siswa Kelas XI IPS 1 SMA Negeri 2 Monosari Tahun Ajaran 2011/2012. Jurnal Pendidikan Akutansi Indonesia. Vol 10 No. 2.

Kuswati, dkk. (2012). Eksperimentasi Metode Discovery dan Metode TPS terhadap Hasil Belajar Matematika Siswa Ditinjau dari Kemampuan Analogi Matematis Siswa SMP Kelas VIII Negeri 26 Purworejo Tahun 2011/2012. Prosiding, Seminar Nasional Matematika dan Pendidikan Matematika. Yogyakarta: UNY.

Marlina, dkk. (2014). Penggunaan Model Pembelajaran Kooperatif Tipe TPS untuk Meningkatkan Kemampuan Komunikasi dan Disposisi Matematis Siswa di SMA Negeri 1 Bireuen. Jurnal Didaktik Matematika. Vol. 1 No. 1.

Bellina. S., \& Motlan. (2013). Pengaruh Model Pembelajaran Kooperatif Tipe Think Pair Share Berbasis Praktikum Terhadap Hasil Belajar Siswa Pada Materi Pokok Listrik 
Dinamis di Kelas X Semester II SMA Negeri 1 Siborongborong T.P. 2012/2013. Inovasi Pembelajaran Fisika (INPAFI). Vol 1 No. 3.

Mufidah, Lailatul. (2013). Penerapan Model Pembelajaran Kooperatif Tipe TPS untuk Meningkatkan Aktivitas Belajar Siswa pada Pokok Bahasan Matriks. Jurnal Pendidikan Matematik. Vol. 1 No. 1.

Nurlaila, F, dkk. (2013). Pengaruh Model Pembelajaran Kooperatif TPS dengan Kecerdasan Logis Matematis terhadap Hasil Belajar Siswa di SMK Negeri 3 Surabaya. Jurnal Pendidikan Teknik Elektro. Vol 2 No. 2.

Saenab, dkk. (2012). Peningkatan Aktivitas dan Hasil Belajar Biologi Melalui Penerapan Model Pembelajaran Kooperatif Tipe TPS pada Siswa Kelas XI IPA 2 SMA Negeri 1 Mangkutana. Jurnal Bionature. Vol 13 No. 2.

Sandra, Rika. (2009). Pengaruh Pembelajaran Kooperatif Tipe TPS terhadap Hasil Belajar Biologi Biologi Peserta Didik pada Pokok Bahasan Peredaran Darah Kelas VIII 6 SMPN 8 Pekanbaru Tahun ajaran 2008/2009. Skripsi: Universitas Islam Riau.

Undang-undang. (2003). UU No. 20 Tahun 2003 tentang Sistem Pendidikan Nasional, Jakarta.

Widyaningsih, S.W. (2011). Pembentukan Karakter Bertanggung Jawab dan Rasa Ingin Tahu Melalui Penerapan Metode Quantum Learning dengan Menggunakan Media Alat Peraga Sederhana pada Pembelajaran Fisika. Prosiding Seminar Nasional MIPA dan Pendidikan MIPA. Padang: Universitas Negeri Padang. Widyaningsih, S.W., \& Yusuf, I. (2015). Penerapan Pembelajaran Listrik Dinamis Model Kooperatif Tipe STAD Menggunakan Pendekatan
CTL dengan Integrasi Nilai-nilai Karakter Terhadap Aktivitas dan Hasil Belajar Peserta Didik. Jurnal Pancaran. Vol. 4 No. 2.

Widyaningsih, S.W., \& Yusuf, I. (2015). Penerapan Quantum Learning Berbasis Alat Peraga Sederhana untuk Meningkatkan Hasil Belajar Peserta Didik. Jurnal Panrita. Vol. 10 No. 3.

Yusuf, I., Widyaningsih, S.W., \& Purwati, D. (2015). Pengembangan Perangkat Pembelajaran Fisika Modern Berbasis Media Laboratorium Virtual Berdasarkan Paradigma Pembelajaran Abad 21 dan Kurikulum 2013. Jurnal Pancaran. Vol. 4 No. 2. 